\title{
A NOTE ON THE ANALYSIS OF VIKING SWORDS
}

\author{
UNA NOTA SOBRE EL ANÁLISIS DE ESPADAS VIKINGAS
}

POR

Alan Williams*

\section{Abstract - Resumen}

A large number of swords from the Viking era bear the inscription «VLFBERHT» or a variation on that. The metallurgy of different examples of these swords varies considerably but the metal employed correlates with the spelling of that name. In seeking to determine the origin of these swords, metallurgical studies may guide us, especially as many of the best examples differ considerably from both earlier and later Medieval swords.

Un número importante de espadas de época vikinga llevan la inscripción «VLFBERHT» o una variante de la misma. La metalurgia de diferentes ejemplos de dichas espadas varía considerablemente, pero el metal empleado guarda correlación con la forma en que se escribió dicho nombre. Cuando tratamos de determinar el origen de estas espadas, los estudios metalúrgicos pueden servirnos de guía, especialmente dado que muchos de los mejores ejemplos difieren considerablemente de espadas medievales tanto anteriores como posteriores en el tiempo.

\section{Keywords - Palabras Clave}

Archaeometallurgy; Crucible steel; Viking swords.

Arqueometalurgia; Acero de crisol; Espadas vikingas.

In reply to Astrup and Martens; these authors seem to be surprised at my results, but they are not following the evidence of the metallurgy. Their first error seems to be in assuming that VLFBERHT must have been a maker's name. They state «(Williams) has analysed swords found in several European countries, the majority in Norway, Finland, Estonia and Latvia, but very few from the central parts of Europe where the smithies for ULFBERHT blades are supposed to be situated.» (my italics)

This assumes that we know their place of origin, which we don't. The fact that fewer swords have been found in Christian countries is noted by the authors, but they do not seem to have appreciated its significance. And then they go on to state: «His conclusion, that these swords were probably made in the Baltic area, is untenable. There is a general agreement in archaeology that the genuine ULFBERHT blades are made in Christian environments familiar with the use of the Latin alphabet.» (my italics)

There is no such «general agreement». A suggestion has been made that because these inscriptions used Latin letters then the swords must have been made in a Christian country. This is pure conjecture, and the frequent repetition of this conjecture does not make it evidence. There

\footnotetext{
*Alan Williams, Archaeometallurgist. The Wallace Collection, London. E-mail: armourmetal@ntlworld.com
} 
are many reasons why pagan sword-makers might have used Latin rather than runic letters, both commercial and magical, and a place of manufacture cannot be inferred from that alone.

(A modern example could be a young European person acquiring tattoos of kanji characters - the wearer could not therefore be assumed to be Chinese or Japanese.)

Much of the study of these swords has been linguistic rather than metallurgical, although a large number of analyses of Viking weapons was carried out some years ago by Hauge in Oslo. From his results, it is evident that some of those swords also used hypereutectoid steels, but unfortunately he did not describe any inscriptions and his results have generally been ignored.

The metallurgical evidence does not point to a Western European origin at all.

The manufacture of these +ULFBERH+T blades stops around the $11^{\text {th }}$ century (when the Volga trade route is interrupted) and the use of hypereutectoid steels in swords also stops and does not resume. If these blades had been made in Frankish or Germanic territory, then one might have expected their manufacture (perhaps anonymously) to have continued. But there is no evidence of any swords made in Western Europe from the $12^{\text {th }}$ century onwards which used anything other than low- and medium-carbon steels. One is then led to the conclusion that the + ULFBERH+T blades were made of an imported raw material.

There was an active trade route between the Baltic and crucible-steel-producing areas in Central Asia until the $11^{\text {th }}$ century. The evidence for this is the considerable quantities of Islamic silver coins found in $10^{\text {th }}$ century Scandinavian burials.

Whether there was any trade in crucible steel by other routes is an open question. The swords made in, for instance, Muslim Spain are an unknown quantity, since no metallurgical investigations have, as yet, been undertaken.

Their second error is to assume that a blade can be dated by the shape of its hilt. A great deal of ink has been spilled on this topic, but it should be born in mind that any competent craftsman could have rehilted a sword - and this would have been all the more likely to have happened with a better than average steel blade. All the shape of the hilt can do is tell us when the sword was last assembled.

Thirdly, they go on to say «the normal procedure in metallographic investigations of edged weapons and tools is to analyse the full, alternatively the half section of the blade.» While elsewhere they suggest that «one basic condition in future work should be a close cooperation between archaeologists and metallurgists.» This is unlikely to happen if the «normal procedure» of metallurgists is to section the object. Sectioning undamaged historical objects is simply not permissible. Sometimes a broken blade may be available, and then a section is already present, but frequently excavated blades show only a damaged edge and museum blades few or no damaged areas at all.

But small samples taken from the edge of an excavated blade will still be sufficient to show firstly, the presence of hypereutectoid steels, and secondly, the employment of heat-treatments such as quenching to harden the steel. This will not show whether edges made of hypereutectoid steel have been attached to a core of different metal (although the Stuttgart sword suggests not) but it will demonstrate that such a steel has been employed, and important conclusions may be still drawn from an acceptably small sample.

Fourthly, they complain that «the swords were divided into four groups, according to the spelling of their maker's name (p. 124). Groups A and B have fully readable spellings + ULFBERH+T and +ULFBERHT+, respectively. Groups C and D have variant spellings, and are grouped after the materials used, C: steel swords and D: iron swords... Both C and D have variant spellings, but they are separated by a different principle, and this means that two different principles are used in a division into four groups.»

They seem to have missed the crucial point here; it matters little whether the blades with variant spellings are considered in one group or two. The important point is that none of the 
variant spellings show the use of hypereutectoid steel, and all the blades employing hypereutectoid steels carry only one spelling namely +ULFBERH+T.

They do have one valid criticism: unfortunately it seems that the captions for Figs. $24 \& 26$ have been transposed and Fig. 49 might not be the sword B3 from the Bergen collection (all I can state is that this is the inventory number it bears now) - but that does not alter the thrust of the argument since all three blades bear inscriptions spelled in the same way and all involve hypereutectoid steels.

\section{BIBLIOGRAPHY}

Hauge, T. D. (1946): Blesterbruk og myrjern. Universitetets Oldsaksamling. Oslo. Tab 9, 179-182.

Recibido: 27/07/2011

Aceptado: 30/07/2011 